Vol. 51, n. 5 : pp.981-989, September-October 2008 ISSN 1516-8913 Printed in Brazil

\title{
Reproductive Studies in Ipecac (Psychotria ipecacuanha (Brot.) Stockes; Rubiaceae): Pollen Development and Morphology
}

\author{
Margarete Magalhães Souza ${ }^{1 *}$, Ernane Ronie Martins ${ }^{2}$, Telma Nair Santana Pereira ${ }^{3}$ and \\ Luiz Orlando de Oliveira ${ }^{4}$ \\ ${ }^{1}$ Departamento de Ciências Biológicas; Universidade Estadual de Santa Cruz; Rodovia Ilhéus-Itabuna Km 16; \\ souzamagg@yahoo.com.br; 45650-000; Ilhéus - BA - Brasil. ${ }^{2}$ Núcleo de Ciências Agrárias; Universidade Federal \\ de Minas Gerais; Montes Claros - MG - Brasil. ${ }^{3}$ Laboratório de Melhoramento Genético; Centro de Ciências e \\ Tecnologias Agropecuárias; Universidade Estadual do Norte Fluminense Darcy Ribeiro; Campos dos Goytacazes - \\ RJ - Brasil. ${ }^{4}$ Departamento de Bioquímica e Biologia Molecular; Centro de Ciências Biológicas; Universidade \\ Federal de Viçosa; Viçosa - MG - Brasil
}

\begin{abstract}
The aim of this work was to carry out the reproductive studies on Brazilian accessions of ipecac, Psychotria ipecacuanha. It presented heterostyly, with brevistylous and longistylous flowers. The pollen development was observed from the sections of the anthers embedded in resin. Anther development was normal as usually observed in dicotyledones, displaying four layers: outer epidermis, endothecium, middle layer and inner tapetum. The pollen was bicellular and filled with starch at the microspore stage. Pollen morphology was studied using SEM, which showed pollen polymorphism within and between the two floral morphs. Five types of pollen with reticulate or perforate exine were identified. The characteristics showed that the sexual process was as important as the vegetative propagation for the reproduction of this species.
\end{abstract}

Key words: Ipecac, heterostyly, anther anatomy, microsporogenesis, exine

\section{INTRODUCTION}

Poaia, ipeca or ipecacuanha are terms used in Brazil to designate the medicinal species, Psychotria ipecacuanha (Brot.) Stockes known as ipecac in English and raicilla in Central America countries (Torres, 1972). Its center of origin is in American continent. The native populations are restricted to three regions: Central America, Southwest of the Brazilian Amazon region (Mato Grosso and Rondonia States) and Atlantic forest, mainly in Minas Gerais, Espírito Santo, Rio de Janeiro and Bahia States (Assis, 1992).

For the commercial cultivation, ipecac may be propagated by the sexual and asexual methods (Jha et al., 1988). The natural propagation occurs by the both vegetative multiplication and seeds that are transported by the birds, but the former is more important (Sick, 1993). This species presents heterostyly (Martins, 2000) like many others species belonging to its family, Rubiaceae (for

*Author for correspondence 
reviews, see Vuilleumier, 1967; Bir Bahadur, 1968).

According to Akerele et al. (1991), $P$. ipecacuanha was considered one of the important medicinal plants in the world. The more remarkable medicinal characteristics are found in the roots with its bitter taste and nauseating smell (Gattoni, 1960; Oliveira and Martins, 1998). The main components responsible for its therapeutic applications are the alkaloids emetine, cephaeline and psycothrine (Sousa et al., 1991). These components provoke vomiting (Sousa et al., 1991), act as expectorant and could be used against Entamoeba hystolitica (Bruneton, 1995), among other applications (Trease and Evans, 1989; Sousa et al., 1991; Carrinconde, Moraes and Fritschen, 1995). Although ipecac is able to arise from the vegetative multiplication, the root collection has been a destructive procedure and the Atlantic forest plants suffered greater reduction in their population (Addor, 1945; Oliveira and Martins, 1998). In Brazil, the production ranged from 30 to $40 \mathrm{~g}$ of dry root per plant, after three years of the cultivation (Gattoni, 1960) but the percentage of alkaloid might reach up to 2.11 after two years (Pinto, 1972). The world demand of the product is estimated to be 100 tons per year (Assis, 1992) which is mainly from the natural vegetation. Only 7-10 tons are produced in commercial cultivation from India (Assis, 1992; Oliveira and Martins, 1998).

Ipecac is considered a threatened species as others Brazilian native species that are disappearing due to diminution of their habitats in the natural vegetation areas (Oliveira and Martins, 1998). The diversity or variation that is present in the natural populations is the resistance base for the environmental pressures, which are the raw material for the natural selection (Brown, 1988). Many wild species have suffered reduction in their genetic base due to predatory collection or vegetation cover destruction (McKeown, 1996). This can lead them to be endangered by the natural selection action (Brown, 1988). The multidisciplinary knowledge can lead to comprehension of genetic components as well as environmental components for giving support to new preservation strategy and reintroducing this species in the conservation units to keep their natural diversity (Oliveira and Martins, 1998). Thus, this study aimed at documenting and reporting valuable information on the male gamete development and pollen morphology to provide a better understanding of the reproductive aspects as well as the importance of the sexual reproduction in this species despite of its considerable medicinal importance.

\section{MATERIALS AND METHODS}

Psychotria ipecacuanha accessions from Brazil were collected from Caratinga and Carangolas (Minas Gerais), and Itaperuna (Rio de Janeiro) cities. The plants were kept in the pots in a greenhouse at the Research Support Unit at UENF.

\section{Pollen development}

The anthers were fixed in $2.5 \%$ glutaraldehyde and $4 \%$ formaldehyde in $0.1 \mathrm{M}$ cacodylate buffer ( $\mathrm{pH}$ 7.2) for an hour at room temperature, dehydrated through an ethanol series and embedded in Spurr`s resin (Spurr, 1969). Semithin sections $(1-2 \mu \mathrm{m})$ were cut with a diamond histoknife and stained with methylene blue-azur II (Richardson, Jarett and Finke, 1960), followed by safranin O (Berlyn and Miksche, 1976). Fresh microspores and pollen grains were stained with IKI (iodine dissolved in aqueous potassium iodide solution; Johansen, 1940) to detect starch, being considered positive those ones stained dark blue or brown, and measured using a light microscopy.

\section{Pollen morphology}

Date were obtained observing the heterostyly and accessions. Pollen was transferred to the aluminum stubs with graphite double-sized adhesive tape, air dried and sputter coated with $20 \mathrm{~nm}$ of gold. Palynological terminology followed Punt et al. (1994) and Barth and Melhem (1988). The samples were dehydrated through an ethanol series, critical point dried, and mounted onto the aluminum stubs following the same steps used for pollen. A Zeiss 962 scanning electron microscope was used for the SEM observations at 5-15 kV. 


\section{RESULTS}

\section{Pollen development}

Ipecac presented hermaphrodite flowers with five anthers, which were tetrasporangiate (Fig. 1). The anther wall formation followed the basic type, with four layers: outer epidermis, endothecium, middle layer, and inner tapetum that lined the anther locule. During the meiosis I, only one middle layer was observed but some cells closest to the connective displayed anticlinal divisions; tapetum were cytoplasmically dense and gametophytic cells presented thick callose (Fig. 2). During the meiosis II, the tapetum cells showed several vacuoles and the middle layer became thinner (Fig. 3). At the end of second meiotic division four haploid nuclei were observed in different configuration (tetrahedral, linear or others) inside a callose coating.

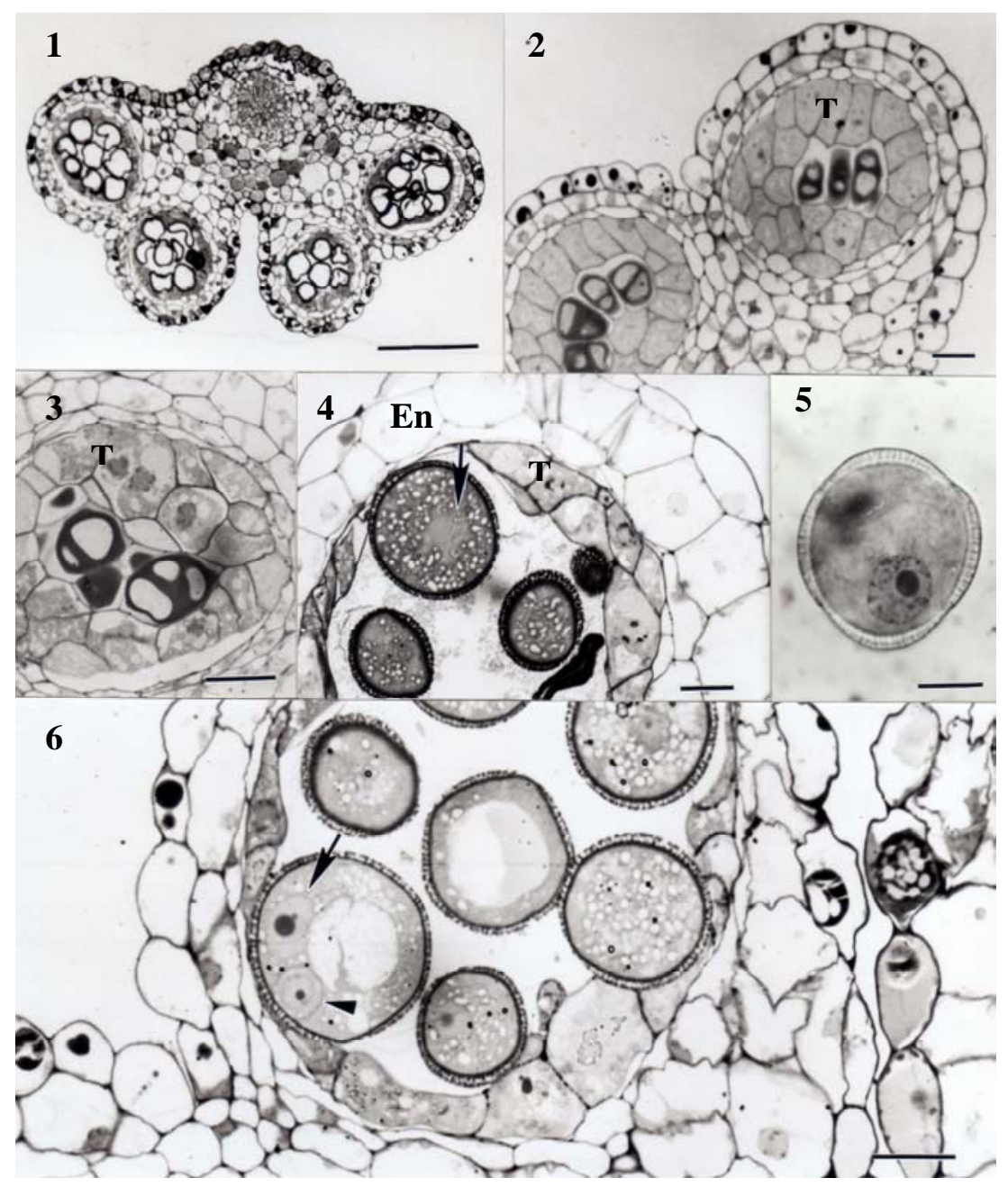

Figure 1 - 6 Staminal characteristics associated to pollen development in Psychotria ipecacuanha. 1) Tetrasporangiate anther. Bar $=200 \mu \mathrm{m}$. 2) Anther locules showing end of meiosis I: tapetum (T) with densely cytoplasmic cells and dyads with thick callose.3) End of meiosis II: tapetum (T) with vacuolated cells and tetrads keeping thick callose. 4) Microspore stage: expanded endothecium (En), degenerating tapetum cells (T) and starchy gametophytic cells showing centralized nucleus (arrow). 5) Late microspore with nucleus near to wall, right before first mitotic division. 6) Early pollen grain stage with large vacuole, vegetative nuclei (arrow) and generative or spermatic cell bounded by a distinct cell membrane (arrowhead). Bars $=20 \mu \mathrm{m}$. 
Using semithin sections, it was observed a sucessive microsporogenesis though the same was not observed by the squashing technique (unpublished date). The microspores were released from the callose with round format and thick exine layer. At the free spore stage, the microspores enlarged and were filled with starch. The endothecium expanded drastically and divided rather periclinally, resulting in the crushing of the middle layer; the tapetum cells remained onenucleate but its degeneration was evident, showing tapetum traces inside the microsporangium (Fig. 4).The microspores nuclei were dislocated near to the wall (Fig. 5). Then they divided to form a small generative cell and a large vegetative cell (Fig 6) while the endothecium reached maximum size. The middle layer cells nearest to the tapetum underwent flattening until total disappearance.

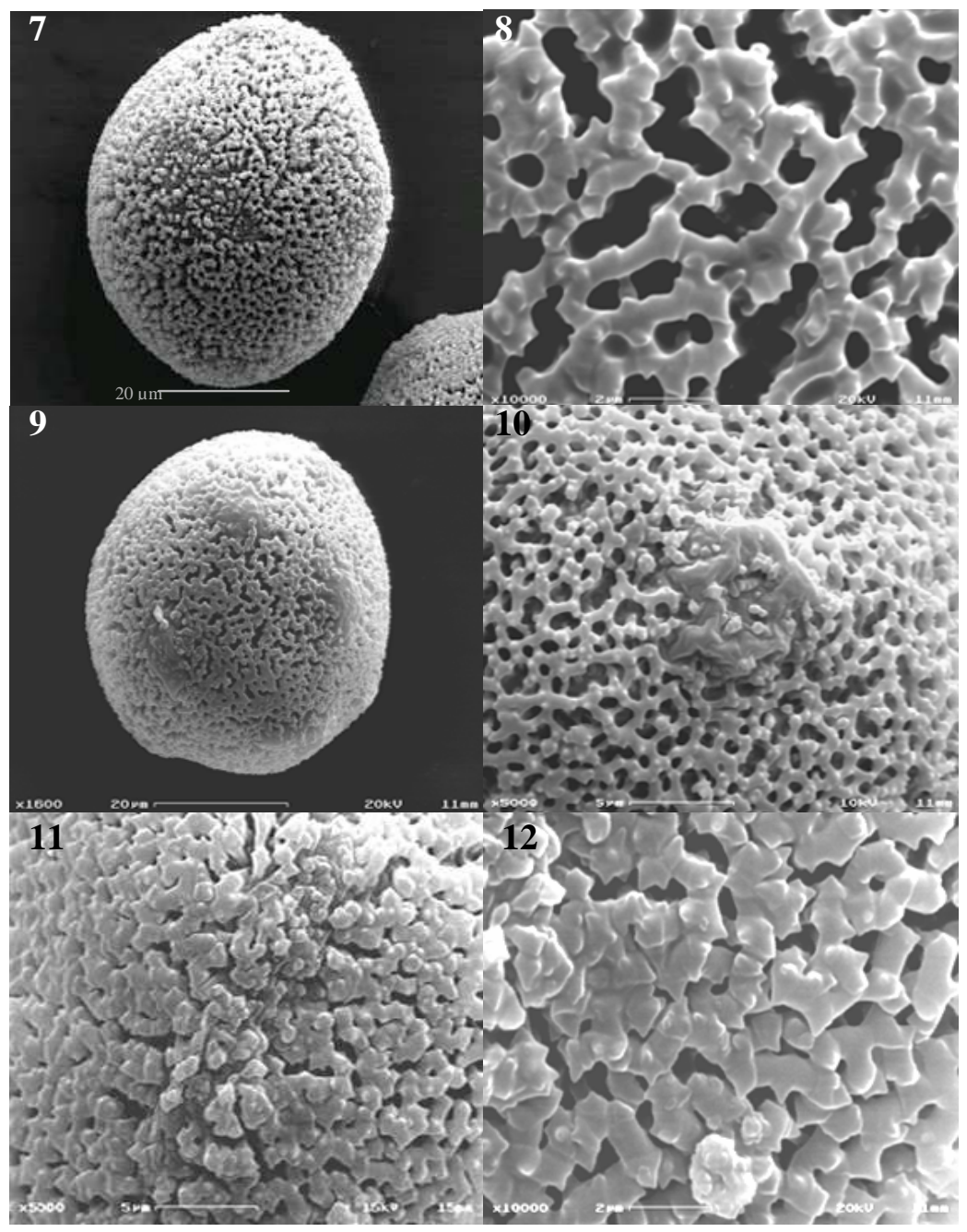

Figure 7 - 12 Pollen morphology from brevistylous flower in Psychotria ipecacuanha. 7) Equatorial view of type I showing reticulate tectum $(B a r=20 \mu \mathrm{m})$. 8) Sexine pattern in equatorial view of type I showing microspines $(B a r=2 \mu \mathrm{m})$. 9) Type II showing reticulate tectum with areas without sexine following a pattern similar to pantoporate grains $(B a r=20 \mu \mathrm{m})$. 10) Sexine pattern of type II showing detail of area without sexine $(\mathrm{Bar}=5 \mu \mathrm{m})$. 11) Detail of the type III surface: note that the tectum forms a densely reticulate ornament and that short, ectexine elements (tectum, collumelae) delineate areas like colpus $(B a r=5 \mu \mathrm{m}) .12)$ Sexine pattern in equatorial view of type III (microspines) $(\mathrm{Bar}=2 \mu \mathrm{m})$. 
The fully matured pollen grain presented a large vacuole and during the microgametogenesis, the erosion of the tapetal cells by deteriorating of wall edges occurred gradually until only their traces remained. Fresh pollen presented positive reaction to IKI, confirming to be starchy.

\section{Pollen morphology}

The pollen polymorphism was observed within and between the two floral floral morphs (Types I to V; Fig. 7-16). The morphology of the pollen grains found in each floral morph is described in Table 1.

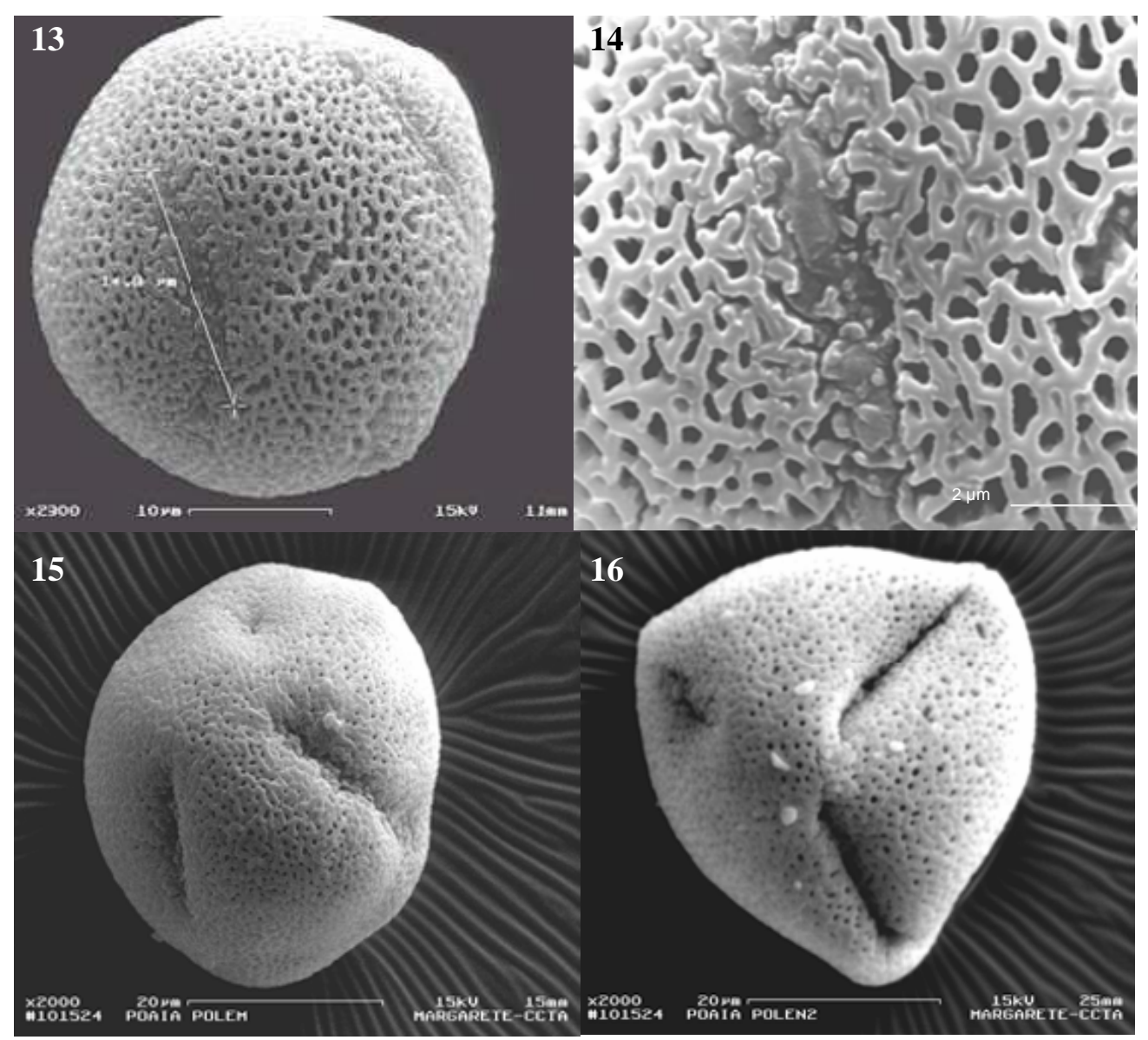

Figure 13 - 16 Morphology of pollen from longistylous flower in Psychotria ipecacuanha. 13) Equatorial view of type IV showing reticulate tectum with white line showing colpus with $14 \mu \mathrm{m}(\mathrm{Bar}=10 \mu \mathrm{m})$. 14) Detail of the type IV apertural surface: note intectate aperture and lightly granular underlying foot layer $(B a r=2 \mu \mathrm{m})$. 15) Equatorial view of type $\mathrm{V}$ showing perforate tectum $(\mathrm{Bar}=20 \mu \mathrm{m})$. 16) Polar view of type $\mathrm{V}$ showing three colpi $(\mathrm{Bar}=20 \mu \mathrm{m})$. 
Table 1 - Morphology of the pollen grains types found in each floral morph in Psychotria ipecacuanha; (minimum and maximum values observed for $\mathrm{P} / \mathrm{E}$ ).

\begin{tabular}{|c|c|c|c|c|c|}
\hline Type & Flower morph & Shape tending to* & Amb & Aperture & Sexine \\
\hline I & Brevistylous & $\begin{array}{c}\text { Subprolato/ } \\
\text { prolato } \\
(1,29-1,37)\end{array}$ & Circular & $\begin{array}{l}\text { Inaperturate; areas less } \\
\text { ornamented are seen in } \\
\text { some points of exine }\end{array}$ & $\begin{array}{l}\text { Reticulate with smooth } \\
\text { tectum separated by a } \\
\text { marked discontinuity; } \\
\text { irregular lumina shape } \\
\text { and size; presence of } \\
\text { supratectal microspines }\end{array}$ \\
\hline II & Brevistylous & $\begin{array}{l}\text { Subprolato/ } \\
\text { prolato } \\
(1,31-1,40)\end{array}$ & Circular & $\begin{array}{l}\text { Pseudoaperturate; } \\
\text { rounded areas without } \\
\text { ornamentation and with } \\
\text { elevation of nexine are } \\
\text { seen on many points of } \\
\text { wall, following a } \\
\text { pattern similar to } \\
\text { pantoporate grains }\end{array}$ & $\begin{array}{l}\text { The same } \\
\text { ornamentation of type } \\
\text { I, but tectum is more } \\
\text { densely arranged }\end{array}$ \\
\hline III & Brevistylous & $\begin{array}{l}\text { Subprolato/ } \\
\text { prolato } \\
(1,18-1,39)\end{array}$ & Circular & $\begin{array}{l}\text { Pseudoaperturate; } \\
\text { elongate areas similar } \\
\text { to short colpi are } \\
\text { marked on exine }\end{array}$ & $\begin{array}{l}\text { Densely reticulate with } \\
\text { supratectal } \\
\text { Microspines and } \\
\text { smooth tectum; } \\
\text { irregularly shaped, } \\
\text { narrow lumina }\end{array}$ \\
\hline IV & Longistylous & $\begin{array}{l}\text { Subspheroidal } \\
(0,90-1,15)\end{array}$ & Circular & $\begin{array}{l}\text { 3-(4)-colpate with } \\
\text { granular nexine }\end{array}$ & Reticulate \\
\hline $\mathrm{V}$ & Longistylous & $\begin{array}{c}\text { Subspheroidal } \\
(0,90-1,17)\end{array}$ & $\begin{array}{l}\text { Subtrian } \\
\text { gular }\end{array}$ & 3-(4)-colpate & Perforate \\
\hline
\end{tabular}

$\mathrm{Amb}=$ the outline in polar view. * The term 'tending to' was used because less than 10 pollen grains per type were measured. $\mathrm{P} / \mathrm{E}=$ polar axis/equatorial diameter (Barth and Melhem, 1988).

\section{DISCUSSION}

The pollen development in the higher plants is a cooperative process requiring multiple interactions between the sporophytic plant and the developing male gametophyte (Chaubal et al., 2000). The anther development can be divided into ten stages. They are based primarily on the state of the male cells and the tapetum, and the surrounding anther wall tissues: sporogenous, mass stages, meiocyte stage, dyad stage, early microspore stage, midmicrospore stage, late microspore stage, early pollen stage, midpollen stage, and late pollen stage, so that the stages 2-7 represent the microsporogenesis and the stages 8-10 represent the microgametogenesis (Horner and Palmer, 1995; Palmer and Horner, 2000).

The tapetum was found to be the secretory type and has the function of producing nutrients and regulatory substances. In soybean (Leguminosae), the vacuolate pollen grains, at stage 8 , start showing signs of the storage that continues to accumulate further (Horner and Palmer, 1995). In $P$. ipecacuanha, starch accumulation was observed in the midmicrospore (stage 6) that, due to the central position of the nucleus, could be distinguished from the late microspore stage. The starch was distinguished due to its characteristic morphology but specific tests to other storage products were not performed in the pollen after quite developed. In the mature pollen grains of Rondeletia, other genus of family Rubiaceae, both starch grains and lipid bodies are found as the storage products: compound starch grains appear first (at the late free microspore stage), but after the first pollen mitosis, oil body accumulation begins and starch contents of the cytoplasm decrease; at anther dehiscence lipids are the main storage product (El-Ghazaly et al., 2001). The reserves can vary among the floral morphs. In Prosopis alba (Mimosaceae), most of the pollen grains proceeding from the medium and shortstyled morphs are rich in oil, and those proceeding from the long-styled morph are rich in proteins 
(Hoc, Garcia and Palacios, 1995). The type of the pollen storage product can be linked to the pollination mechanisms (Baker and Baker, 1979). Although most species of the family Rubiaceae present grains with three nuclei at the maturity (ElGhazaly et al., 2001), the pollen grains of $P$. ipecacuanha were bicellular when shed (Souza et al., 2003). Many heteromorphic species have binucleate pollen (Vuilleumier, 1967).

The sexual process seems to be as important to the reproduction of this species as the vegetative propagation. Reproductive studies were carried out on these same accessions of ipecac by Souza et al. (2006). The pollen viability was analyzed and the percentages ranged between brevistylous and longistylous floral morphs ( 85.3 to $93.1 \%$ ), and among the different localities ( 82.5 to $92.6 \%$ ). The normal anther development associated to microsporogenesis and the existence of differences in the breeding mechanism (heterodistyly) among the populations supported this idea. Heterostyly is thought to have evolved because it confers efficiency of cross-pollination (Björkman, 1995) and favors the allogamy (Robbrecht, 1988). According to Vuilleumier (1967), the heterostylous species can maintain a balance between inbreeding and outbreeding; this flexibility makes it a highly adaptable reproductive system, which can change under different environmental pressures to divergent breeding systems. In Salvia brandegeei, the evolution of distyly might have been associated with an ecological shift to a new environment in which the the geitonogamy: heterostyly was then selected because it increased the proficiency of the crosspollination (Barrett, Wilken and Cole, 2000).

The pollen grains of Rubiaceae have great variation of morphological types and can be considered as being an eurypalynous family (Melhem et al., 1974). This was confirmed by Miranda et al. (1993) who stated that it was possible to recognize a species by the qualitative traits of the exine. The pollen polymorphism in the heterostiylous plants has been documented two centuries ago by Darwin (1877) who noted that there was dimorphism in the reproductive floral parts other than the style and stamen length, as the pollen size, shape, and stigma surface. This was confirmed, for example, in Fagopyrum esculentum by Schoch-Bodmer (1934), where all the pollen grains from the long style plants possessed a certain size, pore shape, and characteristic pollen tube growth, while the pollen from the short style plants differed in all these properties. Chinnappa and Warner (1982) stated that Coffea, the 'pollen polymorphism was a heteromorphic manifestation of anti-self pollinating mechanism, represented by a continuum of aberrant palynomorphs'. Lewis $(1949 ;$ 1954) showed that the heterostyly is governed by $S$ gene that is a super-gene consisting of several linked genes and observed that there were incompatibility genes linked to, but not the identical with, the genes for the two style-stamen ratios, pollen size and stigma surface. According to Silverside (2002), this genetic polymorphism is controlled by a $S$ super-gene with three major components: a) style length - allele $\boldsymbol{G}$ code for a short style, and also shorter papillae on the stigma surface (corroborated by Briggs and Walters, 1997), and the recessive allele $\boldsymbol{g}$ code for a long style and longer stigmatic papillae; b) pollen size allele $\boldsymbol{P}$ code for 'thrum' pollen (from the brevistylous plant), whereas the recessive allele $\boldsymbol{p}$ code for 'pin' pollen (from the longistylous plant), which was only about two-thirds of the diameter of the thrum pollen; c) anther position - allele $\boldsymbol{A}$ code for the anthers in the thrum position at the mouth of the corolla-tube, and the recessive allele $\boldsymbol{a}$ code for the anthers positioned half-way down the tube. With the order GPA, the most frequently occurring recombinants were generated by a single cross-over (Lewis and Jones, 1992).

The heterostyly is often, but not always, associated with the heteropalyny (Robbrecht, 1988). The pollen morphology associated with the heterodistyly has been reported for many species, including species from the family Rubiaceae (Bir Bahadur, 1968; Huysmans et a., 1998). JungMendaçolli and Melhem (1995) studied the pollen morphology of nine species of Psychotria. According the authors, only $P$. cephalantha showed pollen grains colpated; other species were Inaperturated. The pollen of the brevistylous form was larger and the ornamentation (mainly bacula) was more consistent and visible than the longistilous form. The present results agreed with results of Jung-Mendaçolli \& Melhem (1995). In $P$. ipecacuanha, inaperturated and pseudoaperturated pollen grains were observed in brevistylous form and colpus in longistylous form. The pollen of the brevistylous form showed larger $\mathrm{P} / \mathrm{E}$ values and sexine densely reticulate than those of the longistylous form ones. These characteristics certainly are associated to the efficiency of the sexual reproduction in ipecac. 


\section{ACKNOWLEDGEMENTS}

We thank Márcia Adriana S.C. Dutra and Arthur Rodrigues, CBB/UENF Photographic Laboratory technicians for help in developing and amplifying the photographs for this article. This study was supported by FENORTE.

\section{RESUMO}

Foram realizados estudos reprodutivos em acessos brasileiros de poaia, Psychotria ipecacuanha. Poaia apresenta heterostilia, com flores brevistilas e longistilas. O desenvolvimento do pólen foi estudado em cortes de anteras embebidas em resina. $\mathrm{O}$ desenvolvimento da antera seguiu $\mathrm{o}$ padrão normal para as dicotiledôneas, a qual apresentou quatro camadas: epiderme, endotécio, camada média, e tapete, a mais interna. $\mathrm{O}$ pólen apresentou-se bicelular e preenchido com amido no estágio de micrósporo. A morfologia do pólen foi estudada utilizando-se MEV. Foi observado polimorfismo polínico dentro e entre as duas formas florais. Foram identificados cinco tipos de grãos de pólen, com exina reticulada ou perfurada. Em seu hábitat natural, sabe-se que essa espécie apresenta propagação por multiplicação vegetativa, mas as características estudadas demonstraram que o mecanismo sexuado é tão importante para a reprodução dessa espécie quanto à propagação vegetativa.

\section{REFERENCES}

Addor, A. A. (1945), Considerações acerca da poaia. Bol. Minist. Agric. RJ, 34, 1-18.

Akerele, O.; Heywood, V. and Synge, H. (1991), The conservation of medicinal plants. Cambrige University Press, Cambrige.

Assis, M. C. (1992), Aspectos taxonômicos, anatômicos e econômicos da "ipeca" Psychotria ipecacuanha (Brot.) Stokes (RUBIACEAE). Master Dissertation, Universidade de São Paulo (USP).

Baker, H. G and Baker, I. (1979), Starch in angiosperm pollen grains and its evolutionary significance. Am. J. Bot., 66, 591-600.

Barrett, S. C. H.; Wilken, D. H. and Cole, W. W. (2000), Heterostyly in the Lamiaceae: the case of Salvia brandegeei. Plant Syst. Evol., 223, 211-219.

Barth, O. M. and Melhem, T. S. (1988), Glossário ilustrado de palinologia. Campinas: Editora da UNICAMP.
Berlyn, G. P. and Miksche, J. P. (1976), Botanical microtechnique and cytochemistry. The Iowa State University Press, Ames.

Bir Bahadur, B. (1968), Heterostyly in Rubiaceae: a review. Osmania University (Science), Golden Jubilee Volume. pp. 207-238.

Björkman, T. (1995), The effectiveness of heterostyly in preventing illegitimate pollination in dish-shaped flowers. Sex Plant Reprod., 8, 143-149.

Briggs, D. and Walters, S. M. (1997), Plant variation and evolution. Cambridge University Press, Cambridge.

Brown, K. S. (1988), Engenharia ecológica: novas perspectivas de seleção e manejo de plantas medicinais. Acta Amazon., 18, 291-303.

Bruneton, J. (1995), Pharmacognosy, phytochemistry, medicinal plants. Lavoisier, Paris.

Carrinconde, C.; Moraes, D. and Fritschen, M. von. (1995), Plantas medicinais e plantas alimentícias. Centro Nordestino de Medicina Popular, Olinda.

Chaubal, R.; Zanella, C.; Trimnel, M. R.; Fox, T.W.; Albertsen, M.C. and Bedinger, P. (2000), Two malesterile mutants of Zea mays (Poaceae) with an extra cell division in the anther wall. Am. J. Bot., 87, 11931201.

Chinnappa, C. C. and Warner, B. G. (1982), Pollen morphology in the genus Coffea (Rubiaceae). II. Pollen polymorphism. Grana, 21, 29-37.

Darwin, C. (1877), The different forms of flowers on plants of the same species. Murray, London.

El-Ghazaly, G.; Huysmans, S. and Smets, E. F. (2001), Pollen development of Rondeletia odorata (Rubiaceae). Am. J. Bot., 88, 14-30.

Gattoni, L. A. (1960), A raiz de ipecacuanha. A Fazenda, 55, 16-18.

Hoc, P. S.; Garcia, M. T. A. and Palacios, R. A. (1995), Functional Andromonoecy in Prosopis alba Griseb. (Mimosaceae). The effect of abiotic and biotic factors on the reproductive system. Beitr. Biol. Pflanzen, 69, 191-218.

Horner, H. T. and Palmer, R. G. (1995). Mechanisms of genic male sterility. Crop Sci., 35, 1527-1535.

Huysmans, S.; Robbrecht, E. and Smets, E. (1998), A collapsed tribe revisited: pollen morphology of the Insertieae (Cinchonoideae-Rubiaceae). Rev. Palaeobot. Palynol., 104, 85-113.

Jha, S.; Sahu, N. P. and Mahato, B. (1988), Production of the alkaloids emetine and cephaeline in callus cultures of Cephaelis ipecacuanha. Planta Med., 54, 504-506.

Johansen, D. A. (1940), Plant Microtechnique. McGraw Hill, New York.

Lewis, D. (1949), Incompatibility in flowering plants. Biol. Rev., 24, 472-496.

Lewis, D. (1954), Comparative incompatibility in angiosperms and fungi. Adv. Genet., 6, 235-285.

Lewis, D. and Jones, D.A. (1992), The genetics of heterostyly. In: Barret S.C.H., (Ed). Evolution and 
function of heterostyly. Monographs on theoretical and applied genetics, vol 15. Springer, New York. pp. 129-150.

Martins, E. R. (2000), Conservação da poaia (Psychotria ipecacuanha): coleta, ecogeografia, variabilidade genética e caracterização reprodutiva. Doctorate Thesis, Universidade Estadual do Norte Fluminense (UENF), Rio de Janeiro.

McKeown, K. (1996), Germplasm conservation on neotropical medicinal plants and a workshop on Fila Chonta in Costa Rica. Acta Hortic. no 426.

Melhem, T. S.; Rossi, C.L.B. and Silvestre, M.S.F. (1974), Pollen morphological studies in Rubiaceae. Hoehnea, 4, 49-70.

Mendaçolli, S. L. J.; Jung-Mendaçolli, L. S.; Melhem, T.S. (1995), Grãos de pólen de espécies heterostílicas de Rubiaceae. Rev. Bras. Bot., 18, 61-93.

Miranda, M. M. B.; Andrade, T. A. P. and Alves, M. H. (1993), Contribuição ao estudo do pólen das Rubiaceae - Tocoyena. Ciên. Agron., 24, 35-38.

Oliveira, L. O. and Martins, E. R. (1998), O desafio das plantas medicinais brasileiras. I - O caso da poaia (Cephaelis ipecacuanha). UENF, Campos dos Goytacazes.

Palmer, R. G. and Horner, H. T. (2000), Genetics and cytology of a genic male-sterile, female-sterile mutant from a transposon-containing soybean population. J. Hered., 91, 378-383.

Pinto, C. M. D. (1972), A ipecacuanha. In: Simposio internacional sobre plantas de interesse económico de la Flora Amazônica - IICA - Trópicos. Informes de conferências, cursos y reuniones, 93. Costa Rica.

Punt, W.; Blackmore, S.; Nilsson, S. and Le Thomas, A. (1994), Glossary of pollen and spore terminology. LPP Foundation, Utrecht.

Richardson, K. C.; Jarett, L. and Finke, E. H. (1960), Embedding in epoxy resins for ultrathin sectioning in electron microscopy. Stain Technol., 35, 313-323.

Robbrecht, E. (1988). Tropical wood Rubiaceae. Characteristics features and progressions. Contribution to a new subfamilial classification. Nationale Plantentium van Belgie, Meise.

Schoch-Bodmer, H. (1934), Zum heterostylieproblem: griffelbeschaffenheit und pollenschlaubwachstum bei Fagopyrum esculentum. Planta, 22, 149-152.
Sick, H. (1993). Birds in Brazil. Princeton University Press, New Jersey.

Silverside, A. J. (2002), Heterostyly in the Cowslip (Primula veris L.). http://www-biol.paisley.ac.uk/ bioref/ Genetics/Primula_heterostyly.html.

Sousa, M. P.; Matos, M.E.O.; Matos, F.J.A.; Machado, M.I.L. and Craveiro, A.A. (1991). Constituintes químicos ativos de plantas medicinais brasileiras. EUFC, Fortaleza.

Souza, M. M.; Martins, E. R.; Pereira, T. N. S.; Oliveira, L. O. (2003), Reproductive studies on ipecac (Cephaelis ipecacuanha (Brot.) A. Rich; Rubiaceae): flower bud and anther size associated to male gamete development stages. Cytologia, 68, 351356.

Souza, M. M.; Martins, E. R.; Pereira, T. N. S.; Oliveira, L. O. (2006), Reproductive studies on ipecac (Cephaelis ipecacuanha (Brot.) A. Rich; Rubiaceae): meiotic behavior and pollen viability. Braz. J. Biol., 66 (1A), 151-159.

Spurr, A. R. (1969). A low viscosity epoxy resin embedding medium for electron microscopy. $J$. Ultrastruct. Res., 26, 31-43.

Torres, L. A. C. (1972). Contribuicion al conocimiento de la Cephaelis ipecacuanha (Brot.) A. Rich., com especial referencia a Colombia. In: Simposio Internacional sobre plantas de interesse económico de la flora Amazônica - IICA - trópicos. Informes de conferências, cursos y reuniones, 93. Costa Rica.

Trease, G. E. and Evans, W. C. (1989), Pharmacognosy. Bailliére Tindal, London.

Vuilleumier, B. S. (1967). The origin and evolutionary development of heterostyly in the angiosperm. Evolution, 21, 210-226.
Received: February 08, 2006; Revised: November 08, 2007; Accepted: May 13, 2008 